\title{
IMPLEMENTATION TEACHING CAMPUS PROGRAM ACTIVITIES (KAMPUS MENGAJAR) ON STUDENTS LEARNING EFFECTIVENESS IN SD NEGERI 1 MEMBALONG BELITUNG
}

\author{
Taufiqulloh Dahlan ${ }^{1}$, Junaidi' ${ }^{2}$, Zulkifli ${ }^{3}$, Amila $^{4}$, Indri Puspita ${ }^{5}$, \\ Jeany Arsy Maqin ${ }^{6}$, Rata Bila Bagi ${ }^{7}$, Tiara Roza ${ }^{8}$ \\ 1,5,7,8 Universitas Pasundan, Bandung, Indonesia \\ ${ }^{6}$ Universitas Pendidikan Indonesia, Bandung, Indonesia \\ ${ }^{2}$ Dinas Pendidikan Kabupaten Belitung, Indonesia \\ ${ }^{3,4}$ SDN 1 Membalong Belitung, Indonesia \\ 1'taufiqulloh@unpas.ac.id, ${ }^{5}$ puspitaindri39@gmail.com, ${ }^{6}$ arsyjeany@gmail.com, \\ 7ratabila17@,gmail.com, ${ }^{8}$ rozatiara9@gmail.com
}

\section{ABSTRACT}

This study aims to examine the effect of teaching program activities to see the effectiveness of student learning at SD Negeri 1 Membalong. During the COVID-19 pandemic, teaching and learning activities were shifted to face-to-face learning. Students learn by using various features provided on the internet. For approximately 1 year studying at home, over time now several schools have implemented a new normal and have carried out face-to-face learning activities, one of which is at SD Negeri 1 Membalong while still paying attention to health protocols. Campus teaching program activities are one of the activities that help teachers in teaching and learning activities, administration and introduction of technology. This campus teaching activity is a program designed by Nadiem Makarim which involves students going directly to schools located in $3 T$ areas (frontier, outermost, remote). This activity has a positive impact on students and schools involved in this activity. The purpose of this article is to see how influential this teaching activity program is, then examine how effectively students study at SD Negeri 1 Membalong during the pandemic. This study uses an interactive qualitative method with complete data collection using observations, interviews and documentation during activities at SD Negeri 1 Membalong.

Keywords: kampus mengajar, SDN 1 membalong belitung, learning activities

\section{A. Introduction}

Education is a very important place for humans. Education is a human provision for a better life in the future. All humans really need education in order to become successful people later. But we know, not all educated people will be successful in the future. But when compared, people who have education are more successful than people who do not have education. Education is an effort to influence and help the nation's children improve their knowledge, physical and good morals to deliver the nation's children to reach their goals as 
high as possible. (Prof. H. Mahmud Yunus and Martinus Jan Langeveld). Education is the main key to build the nation's character. However, education in Indonesia is still a serious problem because there are still many children of the nation who have not received education, and there are even national children who have not received education at all in school. Most underprivileged children have never attended school.

Currently, the Minister of Education and Culture, Mr. Nadiem Anwar Makarim, is organizing a class 1 teaching campus activity program in 2021. The class 1 teaching campus program aims to provide solutions to elementary schools affected by the COVID-19 pandemic, with the assistance of students who actively contribute to students are from various universities. They are the chosen people who have participated in the selection. Students are assigned by the minister to help teachers and school principals carry out learning activities amid the COVID-19 pandemic. Education during this pandemic is very worrying, because it has a very big risk. Currently the learning process is not running effectively. Especially in elementary school. With students from the campus teaching program, it is hoped that they can help with current problems. Elementary school students can also have the opportunity to interact and gain knowledge from campus students teaching from various universities in Indonesia.

Distance learning causes students to be unable to hone their abilities. With this campus teaching activity, students can easily develop their abilities and apply them in elementary school. Students are very influential so that student learning becomes effective. During the COVID-19 pandemic, the role of an educator is very important. In the learning process, students must know the effectiveness of a student through teaching and learning activities. The effectiveness of learning is a success that is based on certain goals by using actions, strategies, or methods that are owned by a campus student teaching. Student learning is said to be effective if the learning objectives have been met.

In the 4.0 revolution era, of course, there is a main need, namely wanting to achieve mastery and 
deepening of literacy and numeracy material. With campus teaching activities, this is certainly a breakthrough in the field of education. This program is expected to be able to make students the best graduates, both soft skills and hard skills, so that they are better prepared with the needs and progress of the times and become superior future leaders later. (Suharyoyo et al., 2020).

The school that is our partner in implementing the Teaching Campus batch 1 in 2021 is SD Negeri 1 Membalong which is located in Membalong Village. The reason we chose to work at SD Negeri 1 Membalong is that it is close to where students live and SD Negeri 1 Membalong is still accredited $\mathrm{C}$. Schools that still have accreditation $\mathrm{C}$ are a requirement to become partners in implementing campus teaching activities for batch 1 in 2021. In addition, SD Negeri 1 Membalong is a school located in the $3 \mathrm{~T}$ area. What is meant by $3 \mathrm{~T}$ areas are Frontier, Disadvantaged, and Remote areas. The lack of teaching staff at SD Negeri 1 Membalong makes this school included in the list of $3 \mathrm{~T}$ regions. This school is located quite far from the city. The distance is approximately 60 kilometers with a distance of about 1 hour 30 minutes.

Based on the explanation above, the topic studied by the researcher in this article contains the Effect of the Teaching Campus Program on the Effectiveness of Student Learning at SD Negeri 1 Membalong.

\section{B. Method of Implementation}

This method is the first step in making the words that the researcher completes into an article. The research was conducted at SD Negeri 1 Membalong which is located at Jl. Gen. A. Yani Membalong, Belitung, Bangka Belitung Islands. The research began on March 22, 2021 until June 26, 2021. The writing of this article used an interactive qualitative approach with observation, interviews and documentation methods. The data collection technique in this article uses the observation method that the researchers did by going directly to the field and the surrounding environment for approximately 3 months. Then conduct interviews with teachers, students and parents, with 
documentation taken in every activity carried out by researchers during this program from the beginning of the plunge to the end of withdrawal. The general purpose of making this article is nothing less and nothing more to provide relevant arguments against the influence of the campus teaching program that is followed by students to develop their abilities, both in the cognitive, affective and psychomotor domains.

This study discusses the Influence of the Teaching Campus Work Program on the Effectiveness of Student Learning at SD Negeri 1 Membalong. By doing this research the writer can find out the effectiveness of student learning in SD Negeri 1 Membalong and can raise the spirit of learning. The effectiveness of student learning at SD Negeri 1 Membalong was influential when this campus teaching program was carried out, from the observations that researchers saw that the enthusiasm of students was very good, especially the application of work programs that had been designed in adapting today's technology in a state of covid-19. Qualitative research is not limited, because it is elaborative and in-depth. The source of this research focuses on journals, the results of interviews with schools, students and parents of students.

Eka Nur Anisa (2013: 5) reveals that the effectiveness of student learning is the goal of learning to be a result of learning. The same thing was expressed by Daryono (2013: 57) effectiveness is the level of achievement of a learning goal. The benchmark of the effectiveness of SD Negeri 1 Membalong students in learning can be seen from the knowledge, skills, and skills. Knowing the effectiveness of a lesson is important because we can know the extent to which students understand the learning that has been given so far whether it has achieved the goal or not. Hamruni (2012: 23) through the principles of effective learning include orientation to goals, activities, individuality, and integrity.

\section{Result and Discussion}

\section{Teaching Campus}

The teaching campus program is a program compiled by Nadiem Makarim as the minister of education and culture (Mendikbud) in producing 
a generation that is superior, creative at heart and prioritizes character values for the provision of life in the present and in the future. The independent teaching campus program is an activity program that involves students to go directly to the field to visit schools that have $\mathrm{C}$ accreditation and are located in $3 \mathrm{~T}$ areas (leading, underdeveloped and remote areas). This campus teaching activity is carried out to improve the learning process for teachers and students to achieve independence. Where the implementation of this teaching campus activity provides opportunities for students throughout Indonesia to be able to make positive changes during their lifetime, especially for targeted schools.

The class 1 teaching campus program which was carried out for 3 months had a lot of perceived benefits. Students who go directly to schools in the $3 \mathrm{~T}$ region (leading, underdeveloped and remote) have many experiences of each. Before going into the field, the students were given briefing for a week to be given direction on what activities to do and the motivation obtained from the resource persons to be given to all students who took part in the campus teaching program. The focus of activities in this teaching campus program is teaching elementary school students about literacy and numeracy and also students assisting teachers and principals in the school administration process and helping use technology for learning media and others.

During the COVID-19 pandemic, which continues and there are still many people from children to adults who are exposed to this disease, it is a concern that exists at this time. As a result, human activities stop and make the whole community do all activities in the house. One of the activities carried out at home is teaching and learning activities where students and teachers should be able to meet and meet each other when studying is now replaced with online learning activities (in the network). This activity has been carried out for approximately 1 year in schools where the area where they live is exposed to COVID-19. For now there are several schools that carry out teaching and learning activities face-toface, with faster school entry hours and still paying attention to health protocols. 
At the beginning of the implementation of the teaching campus at SD Negeri 1 Membalong this required adaptation to the new environment, where the aim of this program was to focus on the field of numeracy literacy and also adaptation in the field of technology to students. Due to the impact of the COVID-19 pandemic which has caused the literacy and numeracy of students to decline. With this program, it is strived to make positive changes for students in learning.

The independent learning campus program is an activity that has a positive impact on teachers and students as well as for school progress. This activity is also very good for students, because they can go directly to the field to see the condition of the school, participate in teaching and learning activities, and help teachers in administrative activities and use of technology. With the arrival of students from this teaching campus, students become enthusiastic about learning, because students have the provisions they have gained during their studies and then implemented it for students, thus creating different and fun learning conditions (Zulkipli, 2021). With this campus teaching activity, it is very helpful for teachers to achieve student learning. When the teacher is on duty outside or is sick, students play an active role in replacing the teacher teaching in the classroom (Abdi Kholis, 2021).

\section{Effectiveness}

The effectiveness of student learning is a result achieved by students in accordance with expectations after the learning process is carried out. (Sadiman: 1987 in Trianto: 2011 p. 20). The effectiveness of a learning is influenced by 2 factors, namely the factor of the teacher or the factor of the learner himself. The factor of the teacher itself is directly related to the planning of learning in the classroom, the planning can be a decision from the teacher himself in terms of organizing learning, implementing learning and evaluating the learning itself. In addition, there are several other factors related to classroom learning activities, namely in the form of lesson content, teaching materials, school environment, teacher behavior, length of learning, structured learning, 
learning locations, and learning strategies. (Anitah, Sri, et al. 2008).

SD Negeri 1 Membalong is the partner we chose for the implementation of Campus Teaching activities batch 1 in 2021. To measure the effectiveness of student learning, researchers conducted direct classroom observations. Researchers try to see the effectiveness of student learning by providing activities that can spur students' capture power in teaching and learning activities in the classroom, where from the results of the activities provided by researchers there are still lacking in students' comprehension. Because each student has a different grasping power. And with this program, it can be seen that the grasping power of every student in SD Negeri 1 Membalong is increasing day by day. Another factor that affects the effectiveness of student learning is the interest of students in following the lesson, and motivating students to be able to increase the effectiveness of student learning.

Submission of material in a lesson, using several applied methods, it is hoped that using various methods will make classroom learning easier for students to understand so that the objectives of the learning are achieved. Learning is declared successful if the cognitive of each student affects the understanding of students. In elementary schools, learning is carried out in a fun, creative, innovative way so that students are not bored in the ongoing learning process. Not only learning in the classroom, but also can be obtained outside of school with experience gained in everyday life. So that the effectiveness of learning can be obtained from these students.

\section{Student Study at SD Negeri 1 Membalong}

Learning is an activity carried out by someone consciously or unconsciously in order to increase his knowledge which is not yet known. (Aprida Pane et al, 2017). This learning activity is interpreted by the interaction between individuals and their environment. The environment in this case includes objects that can influence in terms of gaining knowledge or experience that has not been previously obtained.

In this 21 st century, students are accustomed to learning on their own, 
finding out information to solve existing problems without having to be helped by their parents. This is an activity to train students to think critically and independently in solving existing problems. Learning is not only done at school but learning can be obtained anywhere, and we can get that knowledge anywhere, without having to be in formal activities. Especially in this era of the covid-19 pandemic, all students have to study at home which results in students not meeting face-toface with the teacher, and also the children do not get a detailed explanation from the teacher, so parents play an active role in helping children's learning.

According to Rusman (2017: 215) learning media is an alternative to make it easier for students to learn and learning media is a vehicle to convey learning more interestingly. This is a message or information to provide learning materials to achieve learning objectives. Learning media uses tools to clarify during the learning process (Kustandi \& Sutjipto, 2011: 9).

Based on the results of research conducted by researchers through observations by going directly to schools, it was found that in general the implementation of student learning at SD Negeri 1 Membalong was quite effective, where teaching and learning activities were carried out in schools, due to the low rate of transmission of COVID-19 which was being hit the whole world.

Based on the observations that have been made, the researcher found that the students were still not fluent in reading, so the child was always left behind when reading together with other students. And there are also problems for students who are difficult to calculate additions, don't even memorize multiplication in high class. Therefore, the purpose of this program is for students to assist teachers in the learning process, both in the application of literacy and numeracy that is applied to students.

With this campus teaching activity, we can focus on students who are still having problems in their learning, where students who play a role can focus more on providing learning related to how to improve the reading and arithmetic process of these students. We implement literacy and numeracy activities that can help in the 
development of the student learning process.

\section{Conclusion}

Based on the results of the study, the campus teaching program is a program organized by the Minister of Education and Culture Nadiem Makarim by contributing with students to assist teachers and principals in the learning process, school administration or technology adaptation during the COVID-19 pandemic. By providing opportunities for students to make changes to schools that are accredited C. The changes made by students are positive changes where with this program students help improve the quality of student learning during this covid-19 pandemic.

This activity provides an extraordinary experience for students and schools. where these students get a lot of knowledge outside of their lectures. In this program, students help provide learning literacy and numeracy activities to students one by one so that students can more easily understand learning. So that students are more enthusiastic during the learning process that is taught by students.

\section{E. Acknowledgments}

We would like thank to Universitas Pasundan, Universitas Pendidikan Indonesia, Kemdikbud, Dinas Pendidikan Kabupaten Belitung, and SDN 1 Membalong Belitung, who have helped us in this activity, both materially and non-materially.

\section{REFERENCES}

Ministry of Education and Culture. (2020). Free to learn. Ministry of Education and Culture, 1-19

Pane, Aprida., Dasopang, Muhammad Darwis. (2017). Learning and Learning. Journal of the Study of Islamic Sciences, Vol. 03 No. 2, p. 336.

Hendri, N. (2020). Freedom to Learn; Between Chancellor and Application. e-tech journal. 8 (1). hlm. 1-9.

Atiyah, U., Untari, M. F. A., \& Tsalatsa, A. N. (2019). The Effectiveness of Numbered Head Together (NHT) Learning Model with Crossword Media on Students' Thematic Learning Outcomes. International Journal of 
Elementary Education, 3(1), 46-52.

Nanggala, A., \& Suryadi, K. (2020). Analysis of the Independent Campus Concept in the Perspective of Citizenship Education. Global Citizen Journal: Scientific Journal of Citizenship Education Studies, 9(2), 10-23.

Widiyono, A., Irfana, S., \& Firdausia, K. (2021). Implementation of Independent Learning Through Campus Teaching Pioneers in Elementary Schools. Didactic Method: Journal of Elementary Education, 16(2). 